\title{
Water-Quality Data from Storm Runoff after the 2007 Fires, San Diego County, California
}

\author{
By Gregory 0. Mendez
}

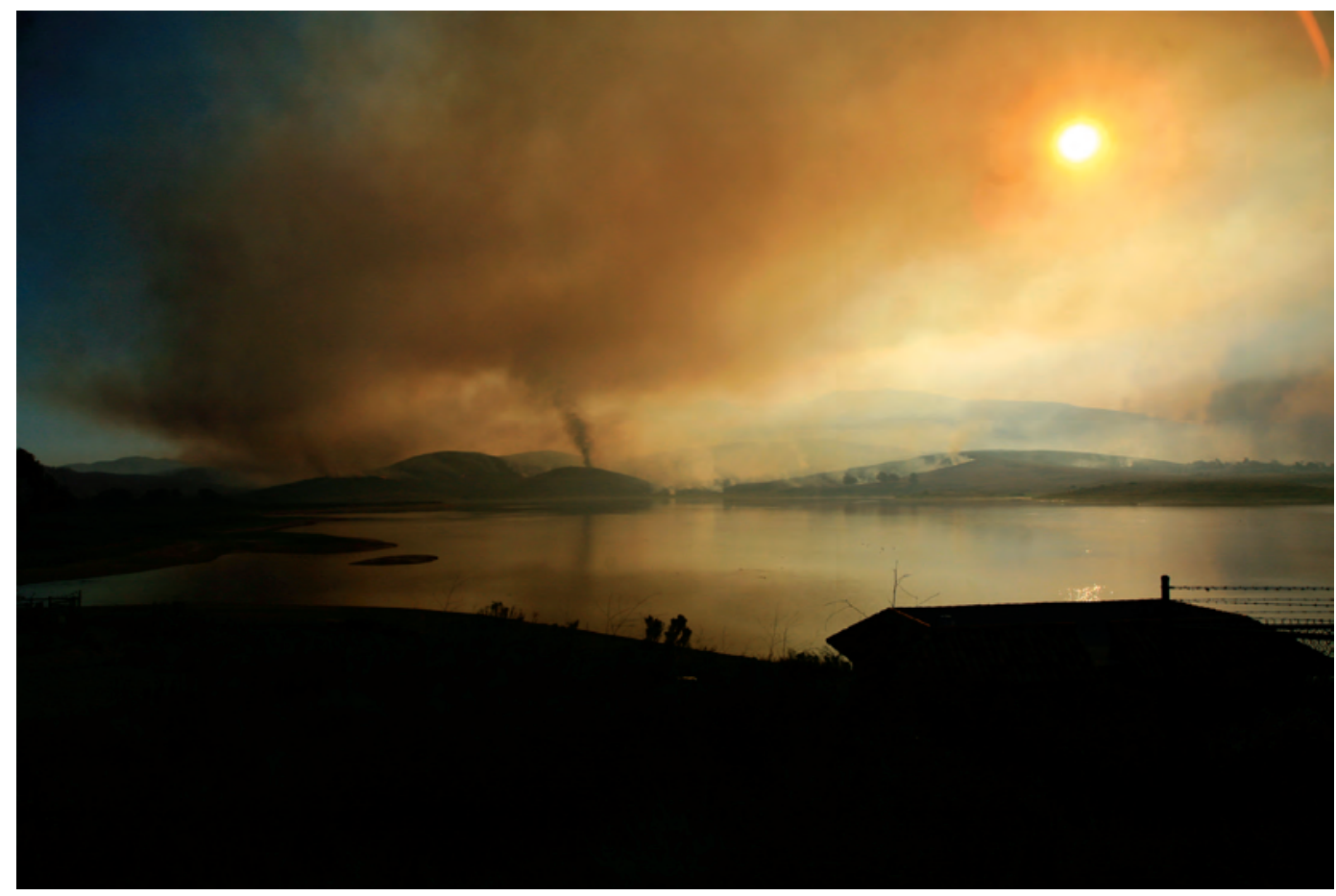

Figure 1. Smoke from the Harris

Fire drifting over Sweetwater

Reservoir, San Diego County,

California.

Photograph taken by Michael S. Majewski, U.S. Geological Survey, October 2007.

$\left(\mathrm{UV}_{254}\right)$ in samples ranged from 0.145 to 0.782 per centimeter $\left(\mathrm{cm}^{-1}\right)$. UV-absorbance data at the urban sites indicate that the composition of DOC remained similar during both storms even though the DOC concentration changed.

Total suspended-sediment concentrations ranged from 7 to $349 \mathrm{mg} / \mathrm{L}$ at the urban area, and were 64,800 and $36,800 \mathrm{mg} / \mathrm{L}$ at the rural area. Trace metals analyzed in unfiltered water samples had lower concentrations in

\section{Abstract}

The U.S. Geological Survey collected water-quality samples during the first two storms after the Witch and Harris Fires (October 2007) in southern California. The sampling locations represent an urban area (two residential sites in Rancho Bernardo that were affected by the Witch Fire; a drainage ditch and a storm drain) and a rural area (Cottonwood Creek, which was downstream of a mobile home park destroyed by the Harris Fire).

Fires produce ash and solid residues that contain soluble chemicals that can contaminant runoff. The contaminants, whether sorbed to soil and ash or dissolved, can seriously affect the quality of water supplies and sensitive ecosystems.

Stormflow water samples were analyzed for field parameters, optical properties, and for a variety of constituents, including nutrients, dissolved organic carbon (DOC), suspended sediment, and metals.
$\mathrm{pH}$ values for storm runoff from the urban areas (7.6 to 8.5$)$ were less than $\mathrm{pH}$ values for ash and burned soil from previous studies (12.5 to 13 ). $\mathrm{pH}$ values for storm runoff from the rural area (about 7.7) also were less than $\mathrm{pH}$ values for ash and burned soil collected from the rural area (8.6 to 11.8 ), but were similar to $\mathrm{pH}$ values for wildland burned soil from previous studies. Turbidity values were much lower for the urban area than for the rural area.

Nitrate concentrations in stormflow samples from all sites were less than a quarter of the U.S. Environmental Protection Agency's (2006) maximum allowable contaminant level of 10 milligrams per liter (mg/L) (as nitrogen). Phosphorus concentrations were half as much in filtered samples and two orders of magnitude smaller in unfiltered samples at the urban sites than at the rural site. DOC concentrations in stormflow samples were one order of magnitude lower at the urban sites than at the rural site. Ultraviolet (UV) absorbance at 254 nanometers the urban area than in the rural area. No concentrations of arsenic or mercury measured in the samples were above aquatic-life criteria. In the urban area, most concentrations of aluminum, iron, and lead exceeded aquatic-life criteria. In the rural area, aluminum, cadmium, iron, lead, and zinc exceeded aquatic-life criteria. Concentrations of aluminum and iron were two orders of magnitude larger in the rural area than in the urban area.

\section{Introduction}

More than 20 fires burned throughout southern California in October 2007. The two largest fires in San Diego County were the Witch and Harris Fires. Smoke from the Harris Fire was extensive, nearly covering Sweetwater Reservoir (fig. 1). The Witch Fire (fig. 2) burned about 200,000 acres of urban and rural landscape and damaged or destroyed 1,125 homes (Federal Emergency Management Agency, 2009). The Harris Fire (fig. 2) burned about 90,000 acres and destroyed more than 200 homes 
(Public Broadcasting Service, 2009). By the second day of the 2007 fires, approximately 500,000 people had received mandatory evacuation orders (San Diego Association of Governments, 2009).

These large fires significantly affect urban and rural areas, but water-quality data following such fires are limited. Urban fires, more than forest fires, can result in increased availability of chemicals and contaminants, mainly in the form of ash and debris. When rains come, contaminants can be mobilized by the rainfall runoff and associated wind. Contaminants, whether sorbed to soil and ash or dissolved in the runoff water, have the potential to seriously affect the quality of water supplies and sensitive habitat areas or ecosystems.

After the fires and before the rains, the U.S. Geological Survey (USGS) collected ash and soil samples in many areas of San Diego County for analysis of metals and other constituents (Plumlee and others, 2007). The $\mathrm{pH}$ of leachate from these ash samples was compared to the $\mathrm{pH}$ in water samples from the post-fire rainfall runoff.

\section{Purpose and Scope}

The purpose of this report is to present water-quality data collected from runoff in two areas burned in the 2007 Witch and Harris Fires. This runoff may contain contamination that can end up in the waterways and reservoirs. Waterquality samples were collected during the first runoff events following the fires. The sampling locations were selected to identify water-quality differences between urban and rural settings and to evaluate runoff that may end up in local drinkingwater reservoirs.

\section{Approach}

Discrete water-quality samples were collected during the first two storms that followed the 2007 San Diego fires. Initial samples were collected shortly after runoff began, followed by periodic sampling during the recession of the storm. Samples were collected during the first storm after the fires (November 30, 2007) in the urban and rural areas. Samples were collected during the second storm after the fires (December 7, 2007) only in the urban area (Rancho Bernardo, at two

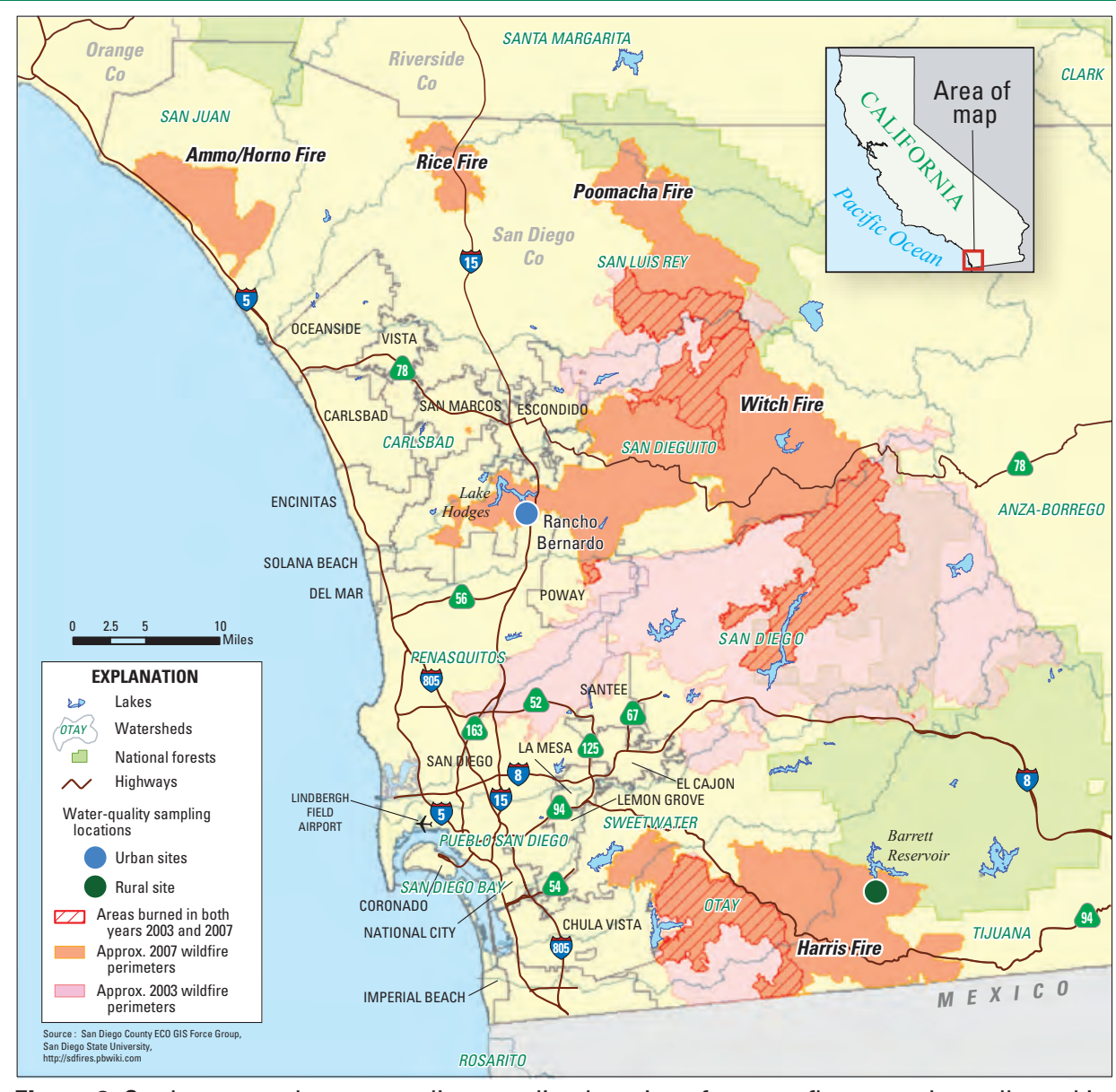

Figure 2. Study area and water-quality sampling locations for stormflow samples collected in Cottonwood Creek and storm drains in Rancho Bernardo, California.

residential sites; fig. 2). The collection of samples from each site included samples used for measurement of field parameters and for analysis of nutrients, organic carbon, UV absorbance, suspended sediment, and trace metals. Partial samples were collected for full-spectrum UV absorbance scans.

\section{Site Selection for Sampling}

The Witch Fire burned part of the upper San Diego River watershed and a large part of the San Dieguito River watershed (fig. 2). Two urban residential sites were sampled (table 1) in the San Dieguito River watershed. Flow from these urban sites drains into Lake Hodges, a drinking-water reservoir. These sites, situated across the street from one another in Rancho Bernardo (fig. 2), were sampled to determine whether there are differences between runoff into a storm drain from a heavily-burned residential hillside and runoff into a drainage ditch from the rest of the neighborhood that was not completely burned. In the burned hillside area, only masonry structures and charred vehicles remained at many of the home sites (fig. 3). Erosion-control devices were installed within days of the fires to reduce the amount of sediment and burned debris transported by runoff.

The Harris Fire burned a large part of the Otay and Tijuana River watersheds (fig. 2). A rural site, on Cottonwood Creek at Barrett Junction below Barrett Reservoir, was sampled (fig. 2); this site is about 1 mile downstream of a mobile home park (fig. 4) that burned and is located near the head waters of the Tijuana River. Hydro-mulch, a slurry of grass seed and mulch that promotes quick germination and inhibits soil erosion, was placed at this location within days after the fire.

\section{Storms Sampled}

Precipitation in San Diego County can be highly variable during most storms, with rain distributed unevenly across the county. The first post-fire storm (November 30, 2007) came from the northwest, and rainfall was not widely distributed across the county. 


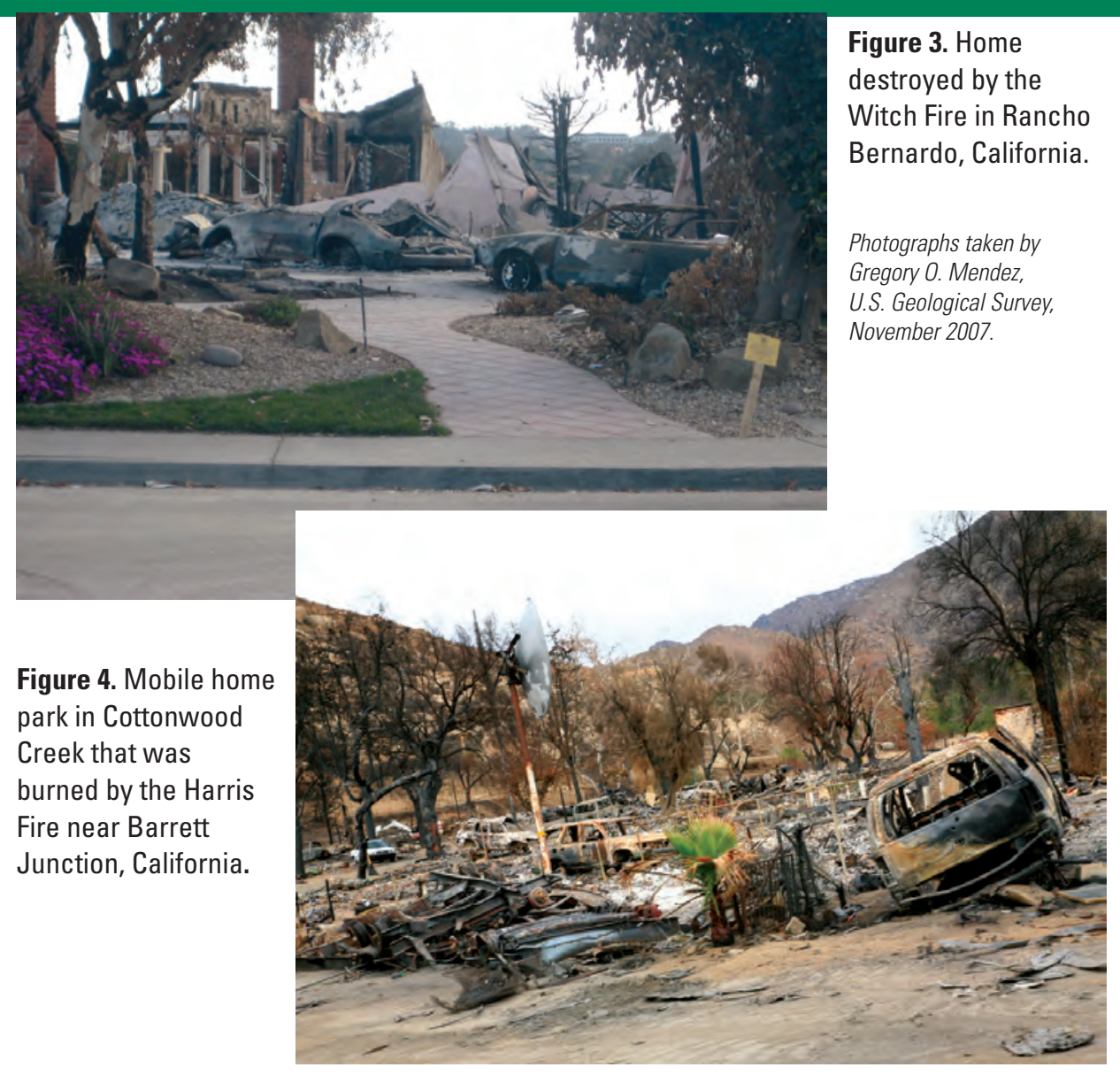

The 24-hour-composite rainfall was 0.0 inches at Otay Reservoir, 0.9 inch at Lindbergh Field airport, 2.0 inches near Rancho Bernardo, 2.6 inches in the foothills to the east, and 2.7 inches in Oceanside to the north (fig. 2). It started

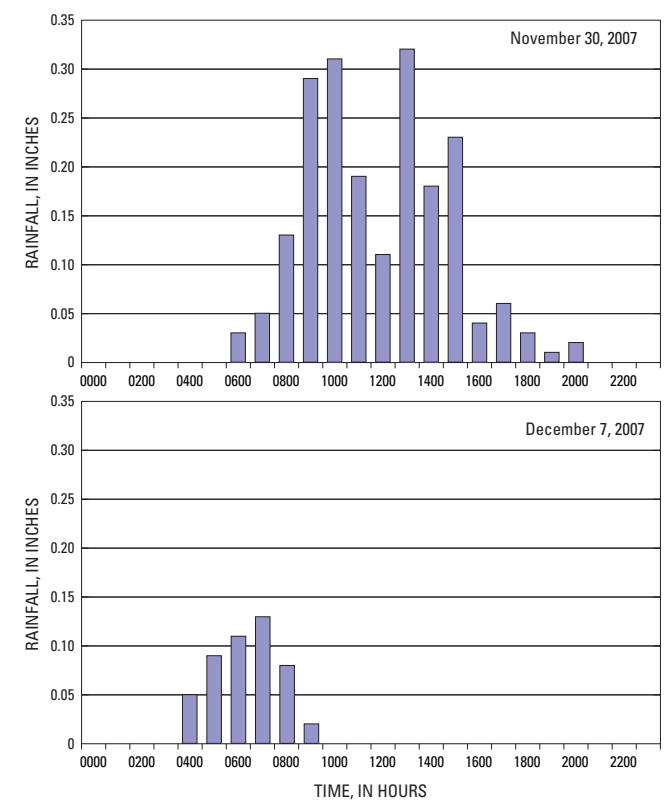

Figure 5. Hourly precipitation in Rancho Bernardo for storm events on November 30, and December 7, 2007. Data provided by Western Solutions, Inc.

U.S. Department of the Interior U.S. Geological Survey Water-quality samples were collected at
4:20 p.m. (1620 hours) and 9:45 p.m. (2145 hours).

During the second storm (December 7, 2007), water-quality samples were collected only at the two urban Rancho Bernardo sites - no samples were collected at the rural site. The 24-hour-composite rainfall in Rancho Bernardo was about 0.5 inches and fell in a few hours (fig. 5). The runoff response to the second storm was recorded in both the ditch and the outflow from the storm drain (fig. 6). Water-quality samples were collected every 2 hours from the ditch and collected every hour from the storm drain, from about 5:00 a.m. (0500 hours) until 7:00 p.m. (1900 hours).

\section{Analytical Methods}

Measurements of water temperature, $\mathrm{pH}$, and specific conductance were taken by using a multi-parameter water sonde. Dissolved-oxygen measurements were taken by using a VVR photometer. Procedures for collecting and processing water samples to determine chemical content were based on established protocols (Shelton, 1994). Storm water-quality samples were collected using either an equal-width increment (EWI) method or a grab-sample method, depending on flow conditions. Samples obtained using the grab-sample method were collected by submerging a churn splitter or a 1-liter (L) glass jar into the center of the channel to collect a sample, then processing the sample into the appropriate

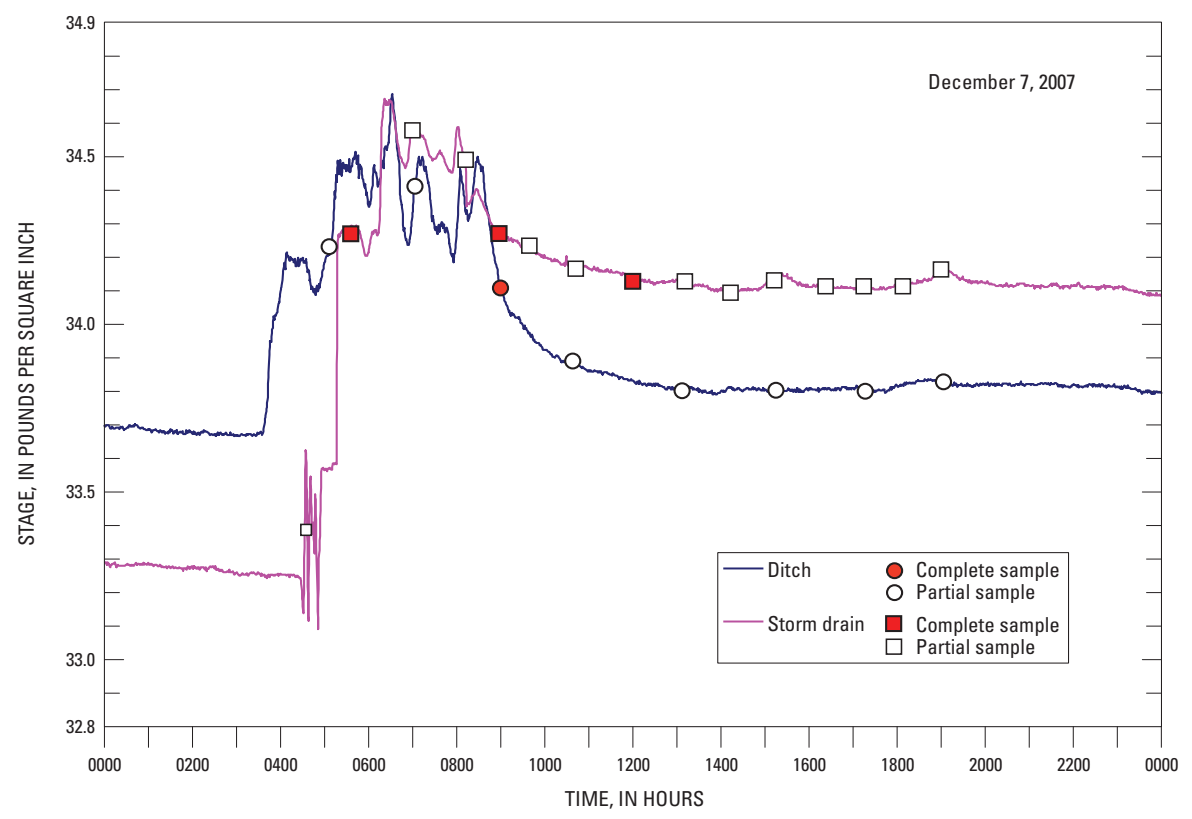

Figure 6. Response to flow for storm on December 7, 2007, Rancho Bernardo, California. 
bottles. Sediment samples were collected in separate bottles by using the EWI method and analyzed using methods described by Guy (1969).

Nutrients, organic carbon, UV absorbance at $254 \mathrm{~nm}$, and metals were analyzed at the USGS National Water Quality Laboratory in Denver, Colorado, by using methods described by Fishman and Friedman (1989), Brenton and Arnett (1993), Fishman (1993), Standard Methods, 19th Edition (1995), Garbarino and Struzeski (1998), Patton and Truitt (2000), Garbarino and Damrau (2001), and Garbarino and others (2006). Fullspectrum optical-property measurements of UV absorbance were made by the USGS laboratory in San Diego, California. UV absorbance was measured from 190 to $400 \mathrm{~nm}$ using a UV/VIS spectrophotometer with a $1 \mathrm{~cm}$ path-length cell.

\section{Water-Quality Data}

Selected water-quality data and field parameters for ten samples are listed in table 1 . The highest alkalinity was in the rural area. During the first storm in the urban area, the alkalinity in the storm drain was about three times the alkalinity in the drainage ditch; during the second

Table 1. Field parameters and selected constituents in stormflow samples collected at Rancho Bernardo and Barrett Junction, California. [UV absorbance, turbidity, alkalinity, and residue on evaporation (ROE) was analyzed at the U.S. Geological Survey (USGS) National Water Quality Laboratory in Denver, Colorado. Sediment samples were analyzed at the USGS sediment laboratory in Marina, California. NTRU, nephelometric turbidity ratio unit; $\mathrm{nm}$, nanometer; $\mathrm{CaCO}_{3}$, calcium carbonate; na, not analyzed; $\mathrm{E}$, estimated value]

\begin{tabular}{|c|c|c|c|c|c|c|}
\hline estimated value] & Station number & $\begin{array}{c}\text { Date } \\
\text { (yyyymmdd) }\end{array}$ & $\begin{array}{c}\text { Sample } \\
\text { time }\end{array}$ & $\begin{array}{c}\text { Location } \\
\text { type }\end{array}$ & $\begin{array}{c}\text { Altitude } \\
\text { of land } \\
\text { surface } \\
\text { (feet) }\end{array}$ & $\begin{array}{c}\text { Absorbance, } \\
\text { UV }_{254} \\
\text { nm, ( per } \\
\text { centimeter) }\end{array}$ \\
\hline \multirow{4}{*}{$\begin{array}{l}\text { Drainage ditch on } \\
\text { West Bernardo } \\
\text { Drive at Rancho } \\
\text { Bernardo }\end{array}$} & \multirow[t]{4}{*}{330226117044001} & 20071130 & 1140 & \multirow[t]{4}{*}{ Urban } & \multirow[t]{4}{*}{360} & 0.339 \\
\hline & & 20071130 & 1430 & & & 0.262 \\
\hline & & 20071130 & 1900 & & & 0.625 \\
\hline & & 20071207 & 0900 & & & 0.210 \\
\hline \multirow{4}{*}{$\begin{array}{l}\text { Storm drain on } \\
\text { West Bernardo } \\
\text { Drive at Rancho } \\
\text { Bernardo }\end{array}$} & \multirow[t]{4}{*}{330225117044101} & 20071130 & 1900 & \multirow[t]{4}{*}{ Urban } & \multirow[t]{4}{*}{370} & 0.782 \\
\hline & & 20071207 & 0600 & & & 0.145 \\
\hline & & 20071207 & 0910 & & & 0.170 \\
\hline & & 20071207 & 1200 & & & 0.536 \\
\hline \multirow{2}{*}{$\begin{array}{l}\text { Cottonwood Creek } \\
\text { at Highway } 94 \\
\text { bridge at Barrett } \\
\text { Junction }\end{array}$} & \multirow[t]{2}{*}{323631116420201} & 20071130 & 1825 & \multirow[t]{2}{*}{ Rural } & \multirow[t]{2}{*}{860} & 0.703 \\
\hline & & 20071130 & 2145 & & & 0.497 \\
\hline
\end{tabular}

storm, the alkalinity values were initially about the same at both sites. Dissolved oxygen ranged from 10 to $11.6 \mathrm{mg} / \mathrm{L}$ in the urban area; no measurement of dissolved oxygen was made in the rural area. $\mathrm{pH}$ values in storm samples in the urban area ranged from 7.6 to 8.5 units, and $\mathrm{pH}$ values in the rural area were 7.8 and 7.7 units. Both ranges of $\mathrm{pH}$ values were significantly below residential ash and burned soil values (12.5 to 13 units) obtained from a 5-minute leach test (Hageman, 2007). pH values for storm runoff from the urban area were similar to those for wildland burned soil from a 5-minute leach test (Hageman, 2007), but most samples had lower alkalinity. $\mathrm{pH}$ values for storm runoff from the rural area were less than $\mathrm{pH}$ values for ash and soil from the mobile home park that burned, 12.5 and 10.6 units, respectively (site Harris 07; Plumlee and others, 2007), but were similar to those for local burned soil samples (site Harris 06; Hageman and others, 2008). Turbidity values for the rural area $(15,700$ to 22,700 nephelometric turbidity ratio units [NTRU]) were orders of magnitude greater than those for the urban area (9.7 to 154 NTRU).

Nitrate concentrations in stormflow samples at all sites were less than a quarter of the maximum contaminant level of $10 \mathrm{mg} / \mathrm{L}$ as nitrogen, as set by the U.S. Environ-mental Protection Agency (2006). Nitrate concentrations at all sites were highest during stormflow recession. Phosphorus concentrations in filtered samples were twice as high in the rural area as in the urban area. Phosphorus concentrations in unfiltered samples were two magnitudes greater in the rural area than in the urban area.

\section{Suspended Sediment}

The highest suspended-sediment concentrations were in the rural area, and 93 to 100 percent of this sediment was finer than 0.062 millimeter $(\mathrm{mm})$. In the urban area, 70 to 84 percent of the suspended sediment in the storm drain was fine-grained (less than $0.062 \mathrm{~mm}$ ) and 56 to 92 percent of the suspended sediment in the drainage ditch was fine-grained. Total-suspended-sediment concentrations in the urban area were lower than those in the rural area, possibly because hay rolls were used in burned areas to minimize erosion.

\section{Organic Carbon}

Ten samples were analyzed for DOC (from filtered water samples) and for total organic carbon (TOC) (for unfiltered water samples) (table 1, fig. 7). DOC concentrations were 180 and $280 \mathrm{mg} / \mathrm{L}$ in the rural area and ranged from 7 to $22 \mathrm{mg} / \mathrm{L}$ in the urban area. The median concentration of DOC in the urban area was $11.8 \mathrm{mg} / \mathrm{L}$. TOC concentrations were 198 and $2,870 \mathrm{mg} / \mathrm{L}$ in the rural area, and ranged from 12.8 to $30.5 \mathrm{mg} / \mathrm{L}$ in the urban area. Both DOC and TOC concentrations were greater in samples from the rural area than from the urban area (fig. 7). High organic carbon concentrations in the rural area are not surprising because water samples from this area were almost black with ash; 
even after filtering, the samples were dark brown.

Knowing the source and composition of organic carbon is important because of environmental concerns associated with DOC having the potential to increase disinfection by-product formation during chlorination of drinking water. Many disinfection byproducts have been shown to cause cancer and developmental effects in laboratory animals (U.S. Environmental Protection Agency, 2006). Since storm runoff at the study sites was not sampled before the two post-fire storms, pre-fire DOC values for unburned conditions at these sites are unknown; however, concentrations of 3 to $5 \mathrm{mg} / \mathrm{L}$ are typical for surface water in arid regions (Thurman, 1986). For comparison, DOC concentrations from the Santa Ana River (in Orange County) ranged from 3 to $15 \mathrm{mg} / \mathrm{L}$, with a median concentration of $6.7 \mathrm{mg} / \mathrm{L}$ (Izbicki and others, 2004).

\section{Ultraviolet Absorbance}

A simplified approach to characterize the composition of DOC is to utilize changes in optical properties of water. Exposure to specific wavelengths of light can result in the absorbance and fluorescence of energy that is related to the presence of specific functional groups within complex carbon molecules. Optical properties of DOC are useful for identification of aromatic (benzene-like ring structures) and aliphatic (carbon compounds not containing benzene ring structures) compounds. Interpretation

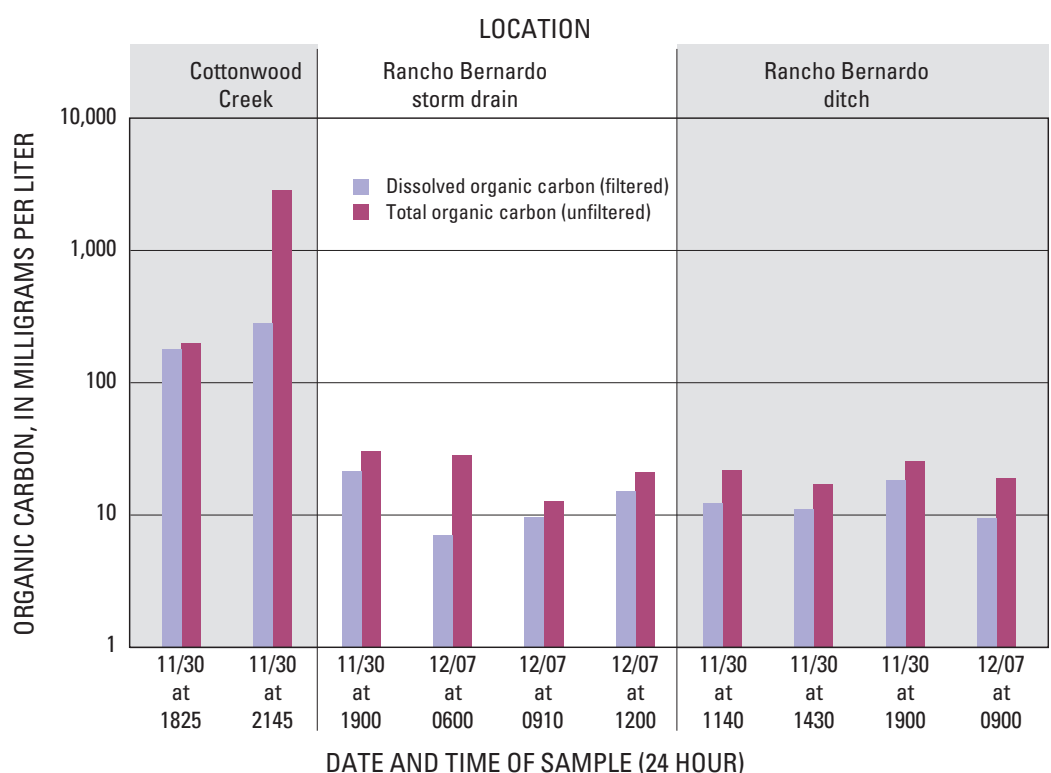

Figure 7. Graph of organic carbon from stormflow samples collected in Cottonwood Creek and Rancho Bernardo, California.

of UV absorbance data does not provide quantitative analysis of DOC; however, a change in UV absorbance can indicate a change in composition of DOC (California Department of Water Resources, 1994; Izbicki and others, 2007). DOC absorbance within the UV range of $220-800 \mathrm{~nm}$ is associated with unsaturated molecules, such as those containing carbon-carbon double bonds or carbon-oxygen double bonds (Gutsche and Pasto, 1975). Carbon-carbon double bonds within aromatic ring structures generally absorb near $254 \mathrm{~nm}$, and carbon-oxygen double bonds generally absorb near $285 \mathrm{~nm}$. The exact absorbance wavelength, however, varies with the length and complexity of associated carbon molecules and other structures (Izbicki and others, 2004). Ring-structure

\begin{tabular}{|c|c|c|c|c|c|c|c|c|}
\hline $\begin{array}{c}\text { Phosphorus, } \\
\text { unfiltered } \\
\text { (milligrams } \\
\text { per liter) }\end{array}$ & 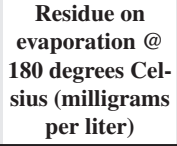 & $\begin{array}{c}\text { Silica, } \\
\text { filtered } \\
\text { (milligrams } \\
\text { per liter) }\end{array}$ & $\begin{array}{c}\text { Silica, } \\
\text { unfiltered } \\
\text { (milligrams } \\
\text { per liter) }\end{array}$ & $\begin{array}{c}\text { Specific } \\
\text { conductance, } \\
\text { field (micro- } \\
\text { siemens per } \\
\text { centimeter) }\end{array}$ & $\begin{array}{c}\text { Suspended } \\
\text { sediment } \\
\text { concentration } \\
\text { (milligrams } \\
\text { per liter) }\end{array}$ & $\begin{array}{c}\text { Suspended } \\
\text { sediment, sieve } \\
>0.0625 \mathrm{~mm} \\
\text { (percent) }\end{array}$ & $\begin{array}{c}\text { Turbidity } \\
\text { (NTRU) }\end{array}$ & $\begin{array}{c}\text { Water } \\
\text { tempera- } \\
\text { ture, field } \\
\text { (degrees } \\
\text { Celsius) }\end{array}$ \\
\hline 0.484 & 113 & 2.59 & 18.4 & 269 & 120 & 91.9 & 71.4 & 16.7 \\
\hline 0.555 & 93 & 2.36 & 24.5 & 142 & 268 & 81.0 & 118 & na \\
\hline na & 456 & 9.94 & 14.3 & 691 & 50 & 56.4 & na & 17.1 \\
\hline 0.389 & 100 & 4.00 & 26.3 & 182 & na & na & 154 & 14.2 \\
\hline 0.409 & 2,220 & 27.3 & 28.0 & na & 7 & 70.2 & 22.6 & 16.2 \\
\hline 0.518 & 123 & 2.88 & 23.3 & 215 & 349 & 77.0 & 104 & 14.1 \\
\hline 0.450 & 246 & 5.33 & 11.2 & 660 & 79 & 84.2 & 46.1 & 14.3 \\
\hline 0.398 & 1,410 & 31.3 & 32.4 & 1,940 & na & na & 9.7 & 16.6 \\
\hline 25.3 & 586 & 6.61 & 275 & 579 & 64,800 & 93.1 & 15,700 & na \\
\hline 65.5 & 969 & 6.90 & 392 & 990 & 36,800 & 99.6 & 22,700 & 15.7 \\
\hline
\end{tabular}

bonds cause smooth curves instead of peaks at wavelengths corresponding to specific functional groups (figs. $8 A, B$ ).

Although UV absorbance was measured from 190 to $400 \mathrm{~nm}$ (figs. 8A,B), analyses were conducted on data collected at $254 \mathrm{~nm}$. UV absorbance at 254 $\mathrm{nm}\left(\mathrm{UV}_{254}\right)$ in samples from the urban area ranged from 0.145 to $0.782 \mathrm{~cm}^{-1}$, with a median absorbance of $0.300 \mathrm{~cm}^{-1}$. $\mathrm{UV}_{254}$ data collected from storm runoff in this study were similar to $\mathrm{UV}_{254}$ data collected from storm runoff on the Santa Ana River (Izbicki and others, 2004). Data from two samples collected at the same time from the urban area during the first storm (November 30, 2007 at 1900 hours) indicate there was about 25 percent more DOC coming through the storm drain than through the drainage ditch across the street. During the second storm, the DOC in the drainage ditch was about the same as that of the DOC in the storm drain.

Nitrate and iron absorb in lower UV ranges (190-230 $\mathrm{nm}$ ), which may have caused the large differences in individual samples in this range. Within the range 230 to $400 \mathrm{~nm}$, more variability for the two storms is observed in the storm drain than in the drainage ditch. UV absorbance at $254 \mathrm{~nm}$ was compared to DOC concentrations (fig. 9) in order to identify differences between samples or between storms. The strong correlation for all samples in both storms $\left(\mathrm{R}^{2}=0.98\right)$ 

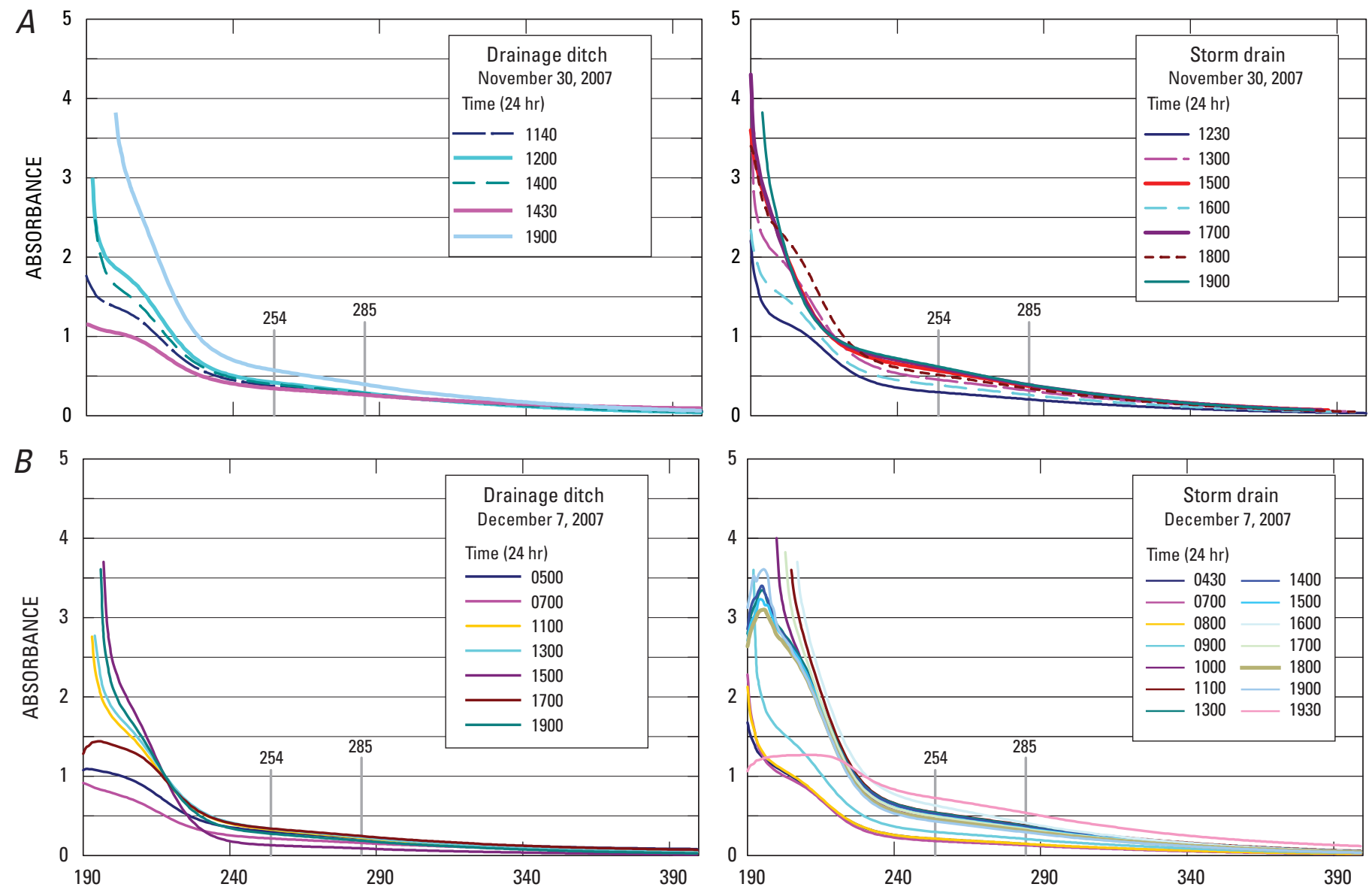

Figure 8. Full-spectrum ultraviolet (UV) absorbance scans for filtered stormflow samples collected in Rancho Bernardo, California drainage ditch for storms of $(A)$ November 30, 2007, and (B) December 7, 2007. [UV Absorbance was analyzed at U.S. Geological Survey Water Quality Laboratory in San Diego, California.]

Figure 9. Dissolved organic carbon (DOC) as a function of $\mathrm{UV}_{254}$ from stormflow samples collected in Rancho Bernardo, California
WAVE LENGTH, IN NANOMETERS suggests that the composition of DOC remained substantially the same.

\section{Metals and Major lons}

Metals (including trace elements) and major ions were analyzed for in filtered and unfiltered water samples (table 2). Metals occur naturally in the environment, but when metals are released into the environment in higher

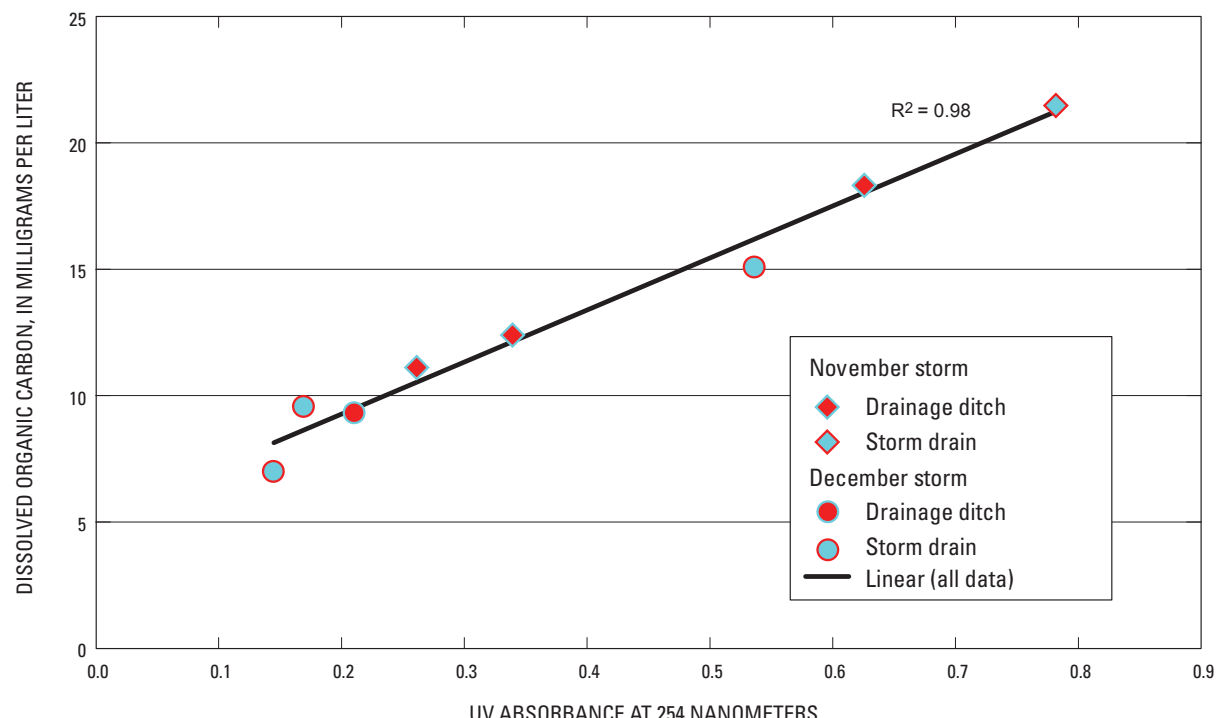

than natural concentrations, they can be problematic because colloidal and dissolved metals may influence the rates and mechanisms of metal bioaccumulation (the accumulation of an environmental compound into an organism). Two aquatic-life criteria that are intended to be protective of the vast majority of the aquatic communities in the United States (U.S. Environmental Protection Agency, 2005) are listed in table 2. Criteria Maximum Concentration (CMC) is an estimate of the highest concentration of a material in surface water to which an aquatic community can be exposed briefly without resulting in an unacceptable effect. The Criterion Continuous Concentration (CCC) is an estimate of the highest concentration of a material in surface water to which an aquatic community can be exposed indefinitely without resulting in an unacceptable effect. Aquatic-life criteria are established for about half of the metals and ions listed in table 2. No concentrations for arsenic or mercury were detected above either $\mathrm{CMC}$ or CCC. In the urban area, most concentrations of aluminum, iron, and lead exceeded both aquatic-life criteria. 
Table 2. Metal (including trace elements) and major-ion concentrations in stormflow samples collected at Rancho Bernardo and Barrett Junction, California. [Analyzed at the U.S. Geological Survey National Water Quality Laboratory in Denver, Colorado. E, estimated value. Shaded columns

represent major ions; $\mu \mathrm{g} / \mathrm{L}$, microgram per liter]

Station name Date Sample $\begin{gathered}\text { filtered } \\ \text { (micrograms }\end{gathered}$ (micrograms $\begin{gathered}\text { unfiltered } \\ \text { (micrograms }\end{gathered}$ (microgr

Criteria Maximum Concentration, $(\mu \mathrm{g} / \mathrm{L})$

Station number

(yyyymmdd) time per liter)

per liter)

per liter)

per liter)

$\begin{array}{ccc}\begin{array}{c}\text { Arsenic, } \\ \text { unfiltered }\end{array} & \begin{array}{c}\text { Cadmium, Cadmium, } \\ \text { filtered }\end{array} & \begin{array}{c}\text { Canfiltered } \\ \text { unf }\end{array}\end{array}$

(micrograms (micrograms (micrograms

Criteria Continuous Concentration, $(\mu \mathrm{g} / \mathrm{L})$

Drainage ditch on West Bernardo Drive at 330226117044001

Rancho Bernardo

$\begin{array}{llll}20071130 & 1140 & 20.0 & 3,710\end{array}$

$\mathbf{7 5 0} 37$

$\mathbf{8 7} \quad 150$

$\begin{array}{lllll}20071130 & 1430 & 21.7 & 3,710 & 2.01 \\ & 1140 & 4.0 & 1.42\end{array}$

$20071130 \quad 1900 \quad 10$

$20071207 \quad 0900 \quad 11.2$

Storm drain on West Bernardo Drive at $330225117044101 \quad 20071130 \quad 1900$

\section{$20071207 \quad 0600$}

$20071207 \quad 0910$

$20071207 \quad 1200$

11.2

994

1.42

1.06

1.07

2.15

1.21

per liter) per liter) per liter) Rancho Bernardo

Cottonwood Creek at Highway 94 bridge $\quad 323631116420201$

$20071130 \quad 1825 \quad 105$

$8.4 \quad 130$

1.93
2.21

2.44

0.063

2.0
0.25

at Barrett Junction

20071130

2145

21,900

0.852

3.22

2.54

2.61

1.98

0.063

0.215

0.215
0.258

(a)

\begin{tabular}{|c|c|c|c|c|c|c|c|c|c|c|}
\hline Station name & Station number & $\begin{array}{c}\text { Calcium, } \\
\text { filtered } \\
\text { (milligrams } \\
\text { per liter) }\end{array}$ & $\begin{array}{c}\begin{array}{c}\text { Chloride, } \\
\text { filtered } \\
\text { (milligrams } \\
\text { per liter) }\end{array} \\
\end{array}$ & $\begin{array}{c}\text { Chromium, } \\
\text { unfiltered } \\
\text { (micrograms } \\
\text { per liter) }\end{array}$ & $\begin{array}{c}\text { Copper, } \\
\text { filtered } \\
\text { (micrograms } \\
\text { per liter) }\end{array}$ & $\begin{array}{c}\text { Copper, } \\
\text { unfiltered } \\
\text { (micrograms } \\
\text { per liter) }\end{array}$ & $\begin{array}{c}\text { Iron, } \\
\text { filtered } \\
\text { (micrograms } \\
\text { per liter) }\end{array}$ & $\begin{array}{c}\text { Iron, } \\
\text { unfiltered } \\
\text { (micrograms } \\
\text { per liter) }\end{array}$ & $\begin{array}{c}\text { Lead, } \\
\text { filtered } \\
\text { (micrograms } \\
\text { per liter) }\end{array}$ & 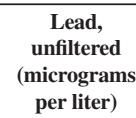 \\
\hline Criteria Maximum Concentration, $(\mu \mathrm{g} / \mathrm{L})$ & & & 860 & & & & & na & 65 & \\
\hline Criteria Continuous Concentration, $(\mu \mathrm{g} / \mathrm{L})$ & & & 230 & & & & & 1,000 & 2.5 & \\
\hline \multirow{4}{*}{$\begin{array}{l}\text { Drainage ditch on West Bernardo Drive at } \\
\text { Rancho Bernardo }\end{array}$} & 330226117044001 & 12.8 & 15.5 & 5.43 & 8.01 & 24.2 & 30.5 & 4,430 & 0.304 & 7.51 \\
\hline & & 11.1 & 13.2 & 7.33 & 8.99 & 35.2 & 26.9 & 6,930 & 0.279 & 9.82 \\
\hline & & 45.8 & 98.7 & 2.99 & 9.37 & 15.3 & 19.7 & 1,040 & 0.177 & 3.00 \\
\hline & & 13.6 & 12.5 & 9.40 & 6.50 & 25.1 & 18.2 & 7,350 & 0.197 & 10.5 \\
\hline \multirow{4}{*}{$\begin{array}{l}\text { Storm drain on West Bernardo Drive at } \\
\text { Rancho Bernardo }\end{array}$} & 330225117044101 & 195 & 646 & 1.38 & 7.97 & 9.1 & 17.4 & 143 & E. 170 & 0.616 \\
\hline & & 15.8 & 13.7 & 8.41 & 5.58 & 70.4 & 16.1 & 6,990 & 0.185 & 16.7 \\
\hline & & 31.6 & 41.4 & 3.40 & 7.42 & 28.1 & 16.5 & 1,840 & 0.386 & 11.7 \\
\hline & & 126 & 268 & 2.90 & 12.1 & 19.4 & 36.1 & 551 & 0.227 & 2.10 \\
\hline \multirow{2}{*}{$\begin{array}{l}\text { Cottonwood Creek at Highway } 94 \text { bridge } \\
\text { at Barrett Junction }\end{array}$} & 323631116420201 & 71.0 & 30.1 & 80.3 & 6.05 & 104 & 110 & 236,000 & 0.145 & 1,030 \\
\hline & & 132 & 63.9 & 42.9 & 6.90 & 322 & 89.5 & 238,000 & 0.148 & 286 \\
\hline Station name & Station number & $\begin{array}{c}\text { Magnesium, } \\
\text { filtered } \\
\text { (milligrams } \\
\text { per liter) }\end{array}$ & $\begin{array}{c}\text { Manganese, } \\
\text { filtered } \\
\text { (micrograms } \\
\text { per liter) }\end{array}$ & $\begin{array}{c}\text { Manganese, } \\
\text { unfiltered } \\
\text { (micrograms } \\
\text { per liter) }\end{array}$ & $\begin{array}{c}\text { Mercury, } \\
\text { unfiltered } \\
\text { (micrograms } \\
\text { per liter) }\end{array}$ & $\begin{array}{c}\text { Potassium, } \\
\text { filtered } \\
\text { (milligrams } \\
\text { per liter) }\end{array}$ & $\begin{array}{c}\text { Sodium, } \\
\text { filtered } \\
\text { (milligrams } \\
\text { per liter) }\end{array}$ & $\begin{array}{c}\text { Sulfate, } \\
\text { filtered } \\
\text { (milligrams } \\
\text { per liter) }\end{array}$ & $\begin{array}{c}\text { Zinc, } \\
\text { filtered } \\
\text { (micrograms } \\
\text { per liter) }\end{array}$ & $\begin{array}{c}\text { Zinc, } \\
\text { unfiltered } \\
\text { (micrograms } \\
\text { per liter) }\end{array}$ \\
\hline Criteria Maximum Concentration, $(\mu \mathrm{g} / \mathrm{L})$ & & & & & 1.4 & & & & & 120 \\
\hline Criteria Continuous Concentration, $(\mu \mathrm{g} / \mathrm{L})$ & & & & & 0.77 & & & & & 120 \\
\hline \multirow{4}{*}{$\begin{array}{l}\text { Drainage Ditch on West Bernardo Drive at } \\
\text { Rancho Bernardo }\end{array}$} & 330226117044001 & 3.59 & 28.4 & 158 & 0.017 & 3.21 & 13.0 & 22.8 & 22.8 & 88.1 \\
\hline & & 2.72 & 21.9 & 221 & 0.025 & 3.00 & 10.6 & 20.2 & 17.2 & 114 \\
\hline & & 20.3 & 76.1 & 112 & 0.015 & 5.80 & 68.5 & 130 & 31.2 & 49.0 \\
\hline & & 3.41 & 29.8 & 210 & 0.017 & 2.63 & 12.9 & 20.1 & 8.03 & 69.4 \\
\hline \multirow{4}{*}{$\begin{array}{l}\text { Storm Drain on West Bernardo Drive at } \\
\text { Rancho Bernardo }\end{array}$} & 330225117044101 & 114 & 47.5 & 67.4 & 0.013 & 11.5 & 353 & 597 & 17.4 & 18.5 \\
\hline & & 2.98 & 15.0 & 212 & 0.067 & 2.67 & 12.7 & 34.3 & 8.69 & 200 \\
\hline & & 7.20 & 27.7 & 84.0 & 0.018 & 4.28 & 33.2 & 74.4 & 17.3 & 66.5 \\
\hline & & 63.5 & 82.8 & 97.3 & 0.024 & 7.40 & 223 & 484 & 25.8 & 33.0 \\
\hline \multirow{2}{*}{$\begin{array}{l}\text { Cottonwood Creek at Highway } 94 \text { bridge } \\
\text { at Barrett Junction }\end{array}$} & 323631116420201 & 18.2 & 637 & 3,480 & $<.010$ & 21.0 & 19.7 & 60.6 & 5.37 & 862 \\
\hline & & 32.6 & 426 & 1,180 & $<.010$ & 24.5 & 35.6 & 135 & 4.56 & 1,790 \\
\hline
\end{tabular}

Chloride concentrations in the storm drain exceeded CCC during the recession of both storms. In the rural area, aluminum, cadmium, iron, lead, and zinc exceeded both aquatic-life criteria.

Concentrations of metals in unfiltered water samples from the first storm at the urban sites were highest in the middle sample, but concentrations decreased throughout the second storm. Concentrations of most trace metals in unfiltered water samples from the storm drain decreased throughout the second storm, whereas the filtered water sample had the highest concentrations in the last sample. At all sites, ion concentrations increased during storm sampling. The rural site had higher concentrations in unfiltered water samples than the urban sites for all metals and ions analyzed except for antimony and mercury. The rural site had higher concentrations of aluminum and manganese in filteredwater samples for than the urban sites.
These high concentrations in water samples may be the result of the composition of debris from the upstream mobile home park that burned.

\section{Conclusions}

Following extensive wildfires in San Diego County in October 2007, water-quality samples were collected in runoff from burned areas, which could have been sources of contamination to waterways or reservoirs. The sampling 
sites were chosen within the two largest burned areas in San Diego County and represented an urban area (two residential sites in Rancho Bernardo: a drainage ditch and a storm drain that were affected by the Witch Fire) and a rural area (Cottonwood Creek, which was downstream of a mobile home park destroyed in the Harris Fire). Samples were collected from runoff during the first two storms following the fires.

Nitrate concentration in stormflow samples were less than a quarter of the maximum contaminant level of $10 \mathrm{mg} / \mathrm{L}$, as nitrogen (U.S. Environmental Protection Agency, 2006). Nitrate values were highest during the recession of the storm. Phosphorus concentrations were twice as high in filtered samples and two magnitudes larger in unfiltered samples from the rural site than from the two urban sites. Total sediment concentrations at the residential sites ranged from 7 to $349 \mathrm{mg} / \mathrm{L}$; the percentage of fines ranged from 56 to 92 . Total sediment concentrations at the rural site were 64,800 and $36,800 \mathrm{mg} / \mathrm{L}$, of which 93-100 percent was fines. Turbidity concentrations in the rural area were hundreds or thousands of times greater than those in the urban area.

DOC concentrations and UV absorbance values were lower in the residential area than in the rural area. DOC concentrations in stormflow samples ranged from 7.0 to $22 \mathrm{mg} / \mathrm{L}$ at the urban sites and from 180 to $280 \mathrm{mg} / \mathrm{L}$ at the rural site. UV absorbance at $254 \mathrm{~nm}\left(\mathrm{UV}_{254}\right)$ in samples from the residential sites ranged from 0.145 to $0.782 \mathrm{~cm}^{-1}$ and at the rural site were 0.703 and $0.497 \mathrm{~cm}^{-1}$. UV-absorbance data indicated that the composition of DOC remained substantially the same during both storms.

Selected metals analyzed for this study had lower concentrations in water from the urban sites than from the rural site. No concentrations of arsenic or mercury were detected above aquatic-life criteria. In the urban area, most concentrations of aluminum, iron, and lead exceeded both aquatic-life criteria. In the rural area, aluminum, cadmium, iron, lead, and zinc exceeded both aquatic-life criteria. Concentrations of aluminum and iron were two orders of magnitude greater in the rural area than the urban area. At all sites, ion concentrations increased with time.

\section{References Cited}

American Public Health Association, American Water Works Association, and Water Environment Federation, 1995, Standard methods for the examination of water and wastewater $\left(19^{\text {th }}\right.$ ed.): Washington, D.C., American Public Health Association, p. 5-60-5-62.

Brenton, R.W., and Arnett, T.L., 1993, Methods of analysis by the U.S. Geological Survey National Water Quality Laboratory-Determination of dissolved organic carbon by UV-promoted persulfate oxidation and infrared spectrometry: U.S. Geological Survey Open-File Report 92-480, $12 \mathrm{p}$.

California Department of Water Resources, 1994, Five-year report of the municipal water quality investigations program: variously paged.

Gutsche, C.D. and Patso, D.J., 1975, Fundamentals of organic chemistry: Englewood Cliffs, New Jersey, PrenticeHall, Inc., 1249 p.

Guy, H.P., 1969, Laboratory theory and methods for sediment analysis: U.S. Geological Survey Techniques of Water-Resources Investigations, book 5 , chap. $\mathrm{C} 1,58 \mathrm{p}$.

Federal Emergency Management Agency, accessed February 12, 2009 at http://www. fema.gov/mitigationbp/bestPracticeDetail. do? mitssId $=5366$

Fishman, M.J., ed., 1993, Methods of analysis by the U.S. Geological Survey National Water Quality Laboratory-Determination of inorganic and organic constituents in water and fluvial sediments: U.S. Geological Survey Open-File Report 93-125, 217 p.

Fishman, M.J., and Friedman, L.C., 1989, Methods for determination of inorganic substances in water and fluvial sediments: U.S. Geological Survey Techniques of Water-Resources Investigations, book 5, chap. A1, 545 p.

Garbarino, J.R., and Damrau, D.L., 2001, Methods of analysis by the U.S. Geological Survey National Water Quality Laboratory-Determination of organic plus inorganic mercury in filtered and unfiltered natural waters with cold vapor-atomic fluorescence spectrometry: U.S. Geological Survey Water Investigations Report 01-4132, $16 \mathrm{p}$.

Garbarino, J.R., Kanagy, L.K., and Cree, M.E., 2006, Determination of elements in naturalwater, biota, sediment, and soil samples using collision/reaction cell inductively coupled plasma-mass spectrometry: U.S. Geological Survey Techniques and Methods, book 5, sec. B, chap. $1,88 \mathrm{p}$.

Garbarino, J.R., and Struzeski, T.M., 1998, Methods of analysis by the U.S. Geological Survey National Water Quality Laboratory-Determination of elements in whole-water digests using plasma-optical emission spectrometry and inductively coupled plasma-mass spectrometry: U.S. Geological Survey Open File Report 98-165, $101 \mathrm{p}$.

Hageman, P.L., 2007, U.S. Geological Survey field leach test for assessing water reactivity and leaching potential of mine wastes, soils, and other geologic and environmental materials: U.S. Geological Survey Techniques and Methods, book 5, chap. D3, 14 p.
Hageman, P.L., Plumlee, G.S., Martin, D.A. Hoefen, T.M., Meeker, G.P., Adams, Monique, Lamothe, P.J., and Anthony, M.W., 2008, Leachate geochemical results for ash and burned soil samples from the October 2007 southern California wildfires: U.S. Geological Survey Open-File Report 2008-1139, 14 p.

Izbicki, J.A., Pimentel, I.M., Johnson, Russell, Aiken, G.R., and Leenheer, Jerry, 2007, Concentration, UV-spectroscopic characteristics and fractionation of DOC in stormflow from an urban stream, southern California, USA: Environmental Chemistry, v. 4, p. 35-48.

Izbicki, J.A., Pimentel, I.M., Leddy, M., Bergamaschi, B.A., 2004, Microbial and dissolved organic carbon characterization of stormflow in the Santa Ana River at Imperial Highway, southern California, 1999-2002: U.S. Geological Survey Scientific-Investigations Report 2004-5116, $71 \mathrm{p}$.

Patton, C.J., and Truitt, E.P., 2000, Methods of analysis by the U.S. Geological Survey National Water Quality Laboratory-Determination of ammonium plus organic nitrogen by a Kjeldahl digestion method and an automated photometric finish that includes digest cleanup by gas diffusion: U.S. Geological Survey Open File Report 00-170, 31p.

Plumlee, G.S., Martin, D.A., Hoefen, T.M., Kokaly, R., Hageman, P.L., Eckberg, Alison, Meeker, G.P., Adams, Monique, Anthony, M.W., and Lamothe, P.J., 2007, Preliminary analytical results for ash and burned soils from the October 2007 southern California wildfires: U.S. Geological Survey Open-File Report 2007-1407, 13 p.

Public Broadcasting Service, accessed February 24, 2009 at kpbs.org/news/fires

San Diego Association of Governments, 2008, 2007 San Diego wildfires: half a million people evacuated, accessed February 24, 2009 at http://www. sandag.org/enewsletter/archives/october2008/ images/2007fireevacuations.pdf

Shelton, L.R., 1994, Field guide for collecting and processing stream-water samples for the National Water-Quality Assessment Program: U.S. Geological Survey Open-File Report 94-455, 42 p.

Thurman, E.M., 1986, Organic geochemistry of natural waters: Boston, Nijhoff and Junk, 497 p.

U.S. Environmental Protection Agency, 2005, National recommended water quality criterialist of recommended water-quality criteria for the protection of aquatic life and human health, accessed March 5, 2010, at http://waterepa. gov/scitech/swguidance/waterquality/standards/ current/index.cfm

U.S. Environmental Protection Agency, 2006, Drinking water contaminants: List of contaminants \& their MCLs, accessed March 5, 2010, at http://www.epa.gov/safewater/mcl.html

For additional information on this report contact

Greg Mendez

4165 Spruance Road, Suite 200

San Diego, CA 92101

(619) 225-6176

e-mail: gomendez@usgs.gov 